VISION: Journal of Indian Taxation Volume 4, Issue 1, January-June 2017, pp. 79-102 doi: 10.17492/vision.v4i01.9995

\title{
Goods and Services Tax (GST): A Comparative Study of Select ASEAN Countries
}

\author{
Surbhi Gupta*
}

\begin{abstract}
After a decade long struggle, overcoming all the issues acting as roadblocks in its implementation, Goods and Services Tax (GST) has finally been implemented in federal India from 1July 2017. By subsuming majority of indirect taxes and cesses levied at the central and state government levels it has simplified the indirect tax regime in India and has put an end to the complex and cascading nature of the multiple tier indirect taxation. GST has already been implemented by more than 160 countries around the world. Hence it carries rich history of successes and failures. In India, both policy makers and public have a lot of expectations from the GST in terms of resolving loopholes in the preexisting indirect tax structure. In this context, this paper attempts to study the functioning of VAT/GST of 6 ASEAN countries - Philippines, Indonesia, Singapore, Vietnam, Thailand and Malaysia - and compare it with the Indian GST regime. An attempt has also been made to draw lessons for India from the experience of these countries. India should learn from the pitfalls in administration and application of law in developing countries as well as from the successful administrative strategies of the developed countries like Singapore.
\end{abstract}

Keywords: Goods and services tax; Value added tax; Indirect taxation; Administration; Tax compliance.

\subsection{Introduction}

Over the years, Value added tax (VAT) also recognised as goods and services $\operatorname{tax}$ (GST) in several countries, has become an important source of indirect taxation. From the mid- $19^{\text {th }}$ century to the early $20^{\text {th }}$ century, many countries relied on the income tax, and there was a global trend of replacing sales tax with the income tax. Gradually, countries began to realise that high income taxes replacing the sales taxes were reducing their global competitive advantage, discouraging investments and incentive for work.

${ }^{*}$ M. Phil. Research Scholar, Department of Commerce, Delhi School of Economics, University of Delhi, Delhi, India. (Email id: SurbhiO8gpt@gmail.com) 
Economies then turned their attention on moving from direct to indirect taxes as a stable source of revenue and reforming their sales tax (Jin and Jin, 2013). Subsequently VAT emerged in context. The concept was first conceived by Wilhelm von Siemens in Germany post-World War I period as a replacement to the country's turnover tax. Finally France pioneered in implementing VAT in 1954 on the recommendation of the French Taxman Apparatchik Maurice Laure. The tax was designed as a 'consumption tax' such that the burden is borne by the final consumer. Since then VAT has been a widely discussed topic in the field of public finance and has been adopted widely throughout the world. It replaced other types of sales tax that were deemed to have serious defects that were not to be found in the VAT.

The Brazilian states and Uruguay were among early converts to the VAT in 1960s. So far more than 160 countries including European Union, Australia, Canada, Japan, New Zealand, Singapore, China, etc. have already implemented GST/VAT in one form or the other. The recent countries to implement GST in the year 2015 are Malaysia and Bahamas. The world's highest indirect taxes are found in Denmark (25\%) and Hungary (27\%). The lowest GST is charged in countries like Canada at 5\%, Malaysia at $6 \%$, Thailand and Singapore at $7 \%$. Since VAT can be levied on both goods and services it has also been termed as 'Goods and Services Tax' popularly known as 'GST.' In some countries GST is known as VAT or HST, but the core idea of GST remains unchanged. 'It is a destination based comprehensive value added tax levied at each stage in the supply chain on the sale and consumption of goods and services within a country with the benefit of the credit of tax paid by the taxpayer on the previous purchases thereby enabling flow of seamless credit across the supply chain' (Gupta, 2016).

Since VAT/GST is a destination based tax, imports are subject to VAT/GST on the same basis as domestic goods and services while exports are not. Different countries have adopted different models of VAT/GST taking into consideration distinct peculiarities of their economies. There are three kinds of GST models which have been adopted worldwide and they are as follows:

(i) GST at the union level or national GST: Under this model, two levels of governments combine their levies in the form of single national GST with appropriate revenue sharing arrangements among them. The tax could be controlled and administered by the centre or states or a separate agency reporting to them. Almost majority of governments in the world are Unitary in nature and they have been implementing single GST. Example- New Zealand, China, Singapore, Japan etc. Although Australia have a federal form of government but GST is collected and administered by the central government and revenue proceeds are shared among the provinces. 
(ii) GST at the state government level or the state GSTs: Under this model, the power to levy and collect GST is with the states only. The centre is withdrawn from the field of consumption taxation. For example, province of Quebec in Canada, where the federal GST is collected and administered by Quebec and the proceeds are remitted to the federal government.

(iii) GST at both the central and union level or dual GST: Under this model, both the levels of governments concurrently have the power to levy tax on all the goods and services, for example, Canada and Brazil. GST is proposed to be implemented in India under this model only.

\subsection{Reasons for adopting GST}

Reasons for adopting the VAT differ from one country to another but some of the widely perceived advantages that seem to have been particularly significant in influencing the policy makers to opt for VAT are:

(i) A properly designed broad based VAT provides more stable revenues than other broad based consumption taxes.

(ii) Compared with other types of consumption taxes like retail sales tax, a VAT is neutral (does not provide business incentive for vertical integration and also promotes equitable distribution of tax burden) and easy to administer.

(iii) It reduces tax fraud and evasion since the tax is levied at each stage in the supply chain. Invoice deduction method i.e. the need for invoices for claiming input tax strengthens the cross auditing relationship between the buyer and seller.

Nonetheless, VAT/GST is not flawless. One of the major disadvantages of VAT/GST is its regressive nature because it is a consumption tax and places undue tax burden on poor people who consume a higher proportion of their income than rich people. VAT/GST also increases compliance cost and burden for businesses especially small and medium enterprises whose profit margins are quite low and are not able to absorb the increased operational and compliance cost under VAT/GST. VAT deduction mechanism makes tax evasion extremely profitable. Reporting false input tax deductions and forging special invoices can be very serious. Despite these limitations, immense benefits of VAT/GST cannot be denied. To counteract the above weaknesses of VAT, the design of VAT reform needs to be detailed and comprehensive along with the development of a sound IT infrastructure.

India, after a decade long struggle, has finally implemented Goods and Services Tax, from 1 July 2017. It has subsumed 17 central and state indirect taxes and around 23 surcharges. It has simplified the indirect tax structure of India by putting an end to the cascading effect of multiple-layer of taxes. GST is a nationwide tax levied on supply of 
goods and services in India. GST is expected to bring a basket of benefits for the Indian economy in terms of buoyant revenues, GDP growth, employment, lower logistics costs and increased exports. However, these benefits are contingent upon the manner of its implementation. GST has already been implemented by more than 160 countries around the world. Hence it carries a rich history of successes and failures. One can study the impacts of VAT/GST on any economy.

\subsection{Rationale and objectives of the study}

This paper attempts to study the functioning of VAT/GST of 6 ASEAN countries namely Philippines, Indonesia, Singapore, Vietnam, Thailand and Malaysia. The rationale behind selecting ASEAN countries is that they are particularly world's fastest developing economies and are becoming more economically integrated with India in terms of trade and investment. These countries also share similar characteristics and experiences of the developing economies (except for Singapore which is a developed economy). In all these countries, indirect taxation has emerged as an important source of revenue over the direct taxes. Both in ASEAN countries and India, income tax is small and poorly distributed, while indirect tax is well established. In this paper, an attempt has also been made to draw lessons for India from the experience of these countries so that India is wary of problems faced by them and initiate special programmes as undertaken by these countries to resolve economic/sector specific issues. These lessons can also help to improve tax compliance and administration which is a key to success for a broad based value added tax.

In the light of the above, the objectives of the study are as follows:

(i) To study the functioning of VAT/GST of the selected ASEAN countries- Singapore, Malaysia, Indonesia, Vietnam, Philippines and Thailand;

(ii) To make a comparative analysis of VAT/GST of the selected ASEAN countries with that of the Indian GST; and

(iii) To draw lessons for India from the experience of selected ASEAN countries under study to make Indian GST more efficient and administratively smooth.

\subsection{Literature Review}

This section reviews some important studies that have examined the implications of implementation of GST/VAT in different countries. Ruangmalai (1992) described the reasons for implementing broad based value added tax in Thailand by replacing the business tax which was introduced in 1961. Rapidly changing Thailand's economy with the growing importance of industrial sector, changes in the legal system to comply with 
GATT commitments, improving the export competitiveness and cascading nature of the business tax resulting from non-recovery of input taxes paid on purchases were some of the reasons for reforming the indirect tax structure in Thailand and introducing VAT. The author also described the nature of VAT, its administration and its economic effect in Thailand soon after its implementation.

Dao and Binh (2013) studied the impact of VAT and income tax in Vietnam on GDP and progressivity using fixed-effects and two-stage Least Squares models together with the regression model of tax progressivity. Cross-sectional time series data over the period 1997-2010 for different 61 provinces in Vietnam was taken. They found that Vietnam's tax policies are progressive and impacts the economic growth positively. However, this may have a negative impact on the economic growth in the long run, because the country can lose competitive advantages to attract foreign investment, if keeping high tax rates.

Palil et al. (2013) obtained the small and medium companies' compliance costs and its elements in Malaysia through a structured questionnaire. They identified three main compliance costs namely 'external costs' i.e. payments made to acquire the services of accountants, tax agents etc; 'internal costs' which relate to the time and money spent by company staff on maintaining and preparing information for professional advisors, complexity of tax forms etc. and lastly 'additional costs' which are incurred by companies related to tax matters like buying tax material, human resource training etc.

Venkadasalam (2014) analysed the post effect of GST on national growth of the selected ASEAN countries namely Philippines, Thailand and Singapore using Least Square Dummy Variable Method. His findings reveal that not all countries in ASEAN are experiencing national growth after implementation of GST. Philippines and Thailand showed a significant negative relationship between GDP and effect of GST. Meanwhile, Singapore showed a significant positive relationship. A positive impact of GST depends on a neutral and rational design of the GST such a way that it is simple, transparent and significantly enhances voluntary compliance.

\subsection{Research Methodology}

This paper is exploratory and descriptive in nature. It aims to acquire insights on GST in the selected ASEAN countries under the study. Available secondary data was extensively used for the study. Different national and international journals, books and websites which focused on various aspects of GST were used for the study. 


\subsection{Structure and Experience of GST/VAT in Selected ASEAN Countries}

\subsection{Goods and Services Tax in Malaysia}

Goods and Services tax was implemented in Malaysia with effect from 1 April 2015. It replaced the Sales Tax Act 1972 and Services Tax Act 1975. Both the sales and services tax were single stage taxes charged only once at the manufacturer and customer level respectively which made it difficult for administrative authorities to identify noncompliance of taxpayers.

The road to the implementation of GST was not easy. It took nearly a decade to implement GST in Malaysia amid various negotiations and public upheaval. Huge budgetary deficits resulting from the Asian Economic Crisis of 1997-98 and declining share of sales and services tax in the national revenue prompted the government to introduce GST in the budget 2005 to replace the sales and services taxes. GST was planned to be implemented in January 2007. However in February 2006 government deferred its implementation due to lack of preparedness among SMEs and enforcement agencies and conflicting views among the masses. The later attempts to introduce GST in 2009 also did not materialise. Finally the GST Bill was once again tabled in the Parliament on $31^{\mathrm{ST}}$ March 2014 and got passed by the majority. GST was implemented from 1 April 2015 as broad based consumption tax levied on taxable supply of goods and services in Malaysia and importation of goods and services into Malaysia at a single uniform rate of $6 \%$ unless supplies qualify for zero rating, exemptions or relief.

There is a large list of goods and services which are either zero rated or exempt to address the problem of regressivity but has made the GST structure more complex. In implementing the broad based consumption tax, the Malaysian government introduced numerous offset packages to compensate for the adverse distributional effects on taxpayers.

- Corporate tax rates were reduced by $1 \%$ effective from the assessment year 2015 .

- Income tax rates for SMEs were reduced from $20 \%$ to $19 \%$ from assessment year 2015 .

- Monetary assistance was initiated to compensate poor households. In the 2016 budget, government allocated MYR 5.9 billion for the "I Malaysia People's Assistance Scheme" to benefit 4.7 million households.

- To counter the effect of initial increase in compliance cost of small businesses post GST, a fund of MYR 100 million was set aside by the government to provide businesses with an opportunity to send their employees for GST training and to provide financial assistance to purchase accounting software for SMEs. 
- Price control and Anti-profiteering Act 2011 was enforced to prohibit the traders from discriminately raising the price of goods and services and not passing the benefit of price fall under GST regime.

\subsubsection{Impact of GST on the Malaysian economy}

The implementation of GST successfully helped the federal treasury to cushion the impact of lower oil revenue due to slump in oil and gas prices. On an annualized basis Malaysia's share of GST in Federal revenue in 2015 was around 17\% and this share is expected to grow over the years (Kasipillai and Kever, 2016). The share of GST taxes in the total federal government's revenue rose gradually from $17 \%$ in 2015 to $18 \%$ in 2016 (Public Sector Finance, Economic Report 2016-17).

There were widespread concerns among the public that GST would be inflationary and people will have to spend more on those goods and services which were earlier not subject to taxes. However in reality, this was not the case as the impact on price levels was controlled with various price control measures being undertaken by the Ministry of Domestic Trade and Consumer Affairs. Consumer prices merely rose $2.1 \%$ year on year basis in April 2016 slowing from 2.6\% increase in March 2016.

According to a study conducted on GST, registered small and medium enterprises post GST revealed that the GST compliance cost in Malaysia was disproportionately high among the small businesses and these entities were not adequately prepared to adopt the new provisions into their existing businesses. Also some of the small businesses were closed because of their inability to cope up with GST regulations.

Royal Malaysian Customs Department (RMCD) highlighted the acute shortage of GST tax agents. As on $30^{\text {th }}$ June 2016, there were over 7,294 GST appeal cases highlighting the volume of taxpayers' grievances. The GST Appeal Tribunal was established effective from 1 April 2015 to provide taxpayers an avenue to appeal against the decision taken by the Director General of RMCD. However drafting of applications and mediating with RMCD to settle disputes is time consuming and costly. Also the compensatory packages to provide financial assistance to SMEs and "I Malaysia People's Assistance Scheme" to minimise the distributional implications of the reform were found to be inadequate. The coverage of the scheme was limited due to tight fiscal situation of the government. The Malaysian government was not even prepared for large amounts of refunds that were needed to be made to GST registrants. Malaysia's experience post GST suggests that pitfalls exist in the administration of tax and application of law. 


\subsection{Value Added Tax in Indonesia}

Indonesia was the first country in the ASEAN group to implement VAT in 1985. Indirect taxes prevalent prior to the introduction of VAT comprised of turnover/sales tax through the manufacturing stage; selected excises on tobacco, beer, sugar, spirits; stamp duties and customs duties. The pre-existing system was extremely complex and cascading in nature resulting in widespread evasion and distortions. So a need was felt to introduce a more simplified, broad based indirect tax structure in Indonesia which could improve the situation. The changes made were comprehensive and well planned. A uniform 10\% VAT (coupled with a higher luxury tax) was introduced in 1985. VAT was introduced as a destination based consumption tax levied on the supply and import of goods and services in Indonesia at the manufacturer's/importer's level employing the tax credit method of collection with zero rating of exports (with the benefit of input tax credit) and certain exemptions (without the benefit of input tax credit). Gradually the VAT was extended till the retail level.

\subsubsection{Effect of VATon Indonesia's economy}

Value-added tax was the cornerstone of the far-reaching tax reforms adopted in Indonesia in 1983. VAT proved to be buoyant in terms of revenue performance. In its first three years of existence, VAT easily fulfilled original expectations and contributed nearly 3\% of GDP, almost three times that of the pre-existing turnover tax. In 2016 the share of VAT in the total tax revenue of the government was $32.07 \%$ making it the second largest source of revenue for the government (Government Finance Statistics, Bank Indonesia, 2016).

In Indonesia, there were widespread apprehensions and predictions by many businessmen and economists that VAT would result in inflation. However, in practice nothing like that happened and VAT was implemented with almost negligible effects on price levels. This was due to two factors. First, substitution of VAT with a cascade tax may have had some price-level effects. Second, policy makers were well aware that the rate of monetary expansion in the first quarter of 1985 had decelerated. However, some of the administrative issues in the beginning placed the revenue potential of the VAT in jeopardy. However, decision makers in the cabinet continued to apply pressure on the VAT administrators to improve performance through 1986 and 1987. By early 1987, progress was notable. Although there were large number of VAT exemptions on items consumed by the lower income groups, however some of these exemptions proved to be more beneficial to the highest income groups. Also large scale exemptions proved harmful for pre retail firms under the tax-credit VAT. 
Presently, the Indonesian government is considering to replace the value-added tax (VAT) system with a more comprehensive and broad based Goods and Services Tax (GST), as part of its plan to boost tax revenue. According to experts, the revision of the VAT Law would boost the country's goods and services tax ratio in relation to the gross domestic product by between $1 \%$ and $4 \%$.

\subsection{Goods and Services Tax in Singapore}

Goods and Services tax in Singapore was a result of broad policy measures undertaken by the Singaporean government to restructure the entire taxation system in order to shift its reliance from direct to indirect taxes. Prior to the introduction of GST Singapore relied heavily on corporate and individual income taxes with top rates being around $40 \%$. But the declining income tax base due to ageing population prompted the government to introduce a broad based GST system where taxation burden would be more evenly distributed among all the sections of the society.

Unlike other countries, the path towards the implementation of GST was not difficult due to lack of strong opposition party against the ruling government and strong public trust in the ruling party. The Finance Minister in 1990 announced the introduction of a comprehensive consumption tax in the Parliament. Over the year the legislation was refined and finally issued on $9^{\text {th }}$ February 1993. The final bill was passed by the Parliament on 12 October 1993 and approved by the President on October 1993. Thereafter, GST came into effect in Singapore on 1 April 1994 at a single rate of 3\% as a broad based consumption tax with only a few exemptions such as sale and lease of residential land and buildings and few financial services. GST in Singapore is a broad based consumption type value added tax levied at each stage in the supply chain from manufacturer to retail level that uses input tax credit method. Unlike other countries GST in Singapore has simplest structure in the world.

The initial rate of $3 \%$ was lowest in the world as the government did not intend to immediately generate revenues from GST but rather to develop it as a future source of revenue and give people some time to adjust to the tax. GST was introduced as a part of overall tax reform package of offsets to overcome the regressive nature of broad based consumption tax. The offset comprised of both permanent and transitory measures (to be implemented for 5 years after the introduction of GST). Some of the measures were:

- Reduction in top corporate income tax rates from 30 to 27\% in 1994 to 26\% in 1997.

- Reduction in top individual income tax rates from 33 to $30 \%$ in 1994 to $28 \%$ in 1996.

- Reduction in the rates of estate duty, property tax, suspension of import and excise duties on several items such as natural gas, lubricating oil etc. 
- Monthly rental rebates for tenants of one and two room public flats.

- A general assistance scheme for small number of financially needy families

Keeping in mind the special features of the Singaporean economy that makes it difficult for a VAT to function such as high ratio of imports and exports to GDP and relatively large financial sector several special schemes were adopted. Some of them are:

- Major exporter scheme (MES): Under this scheme registered qualifying exporters can import goods without paying GST at customs point thus relieving them from reclaiming it back later. This reduces the compliance cost of exporters and need for maintaining books and records.

- Bonded warehouse scheme (BWS): Under this scheme, GST is suspended on imported goods that enter Singapore and are stored in bonded warehouses. GST is not levied on goods that are not removed from the bonded warehouse for re-export or transfer from one bonded warehouse to another.

- Special rules for Banking and financial companies for claiming input tax credit: Pre-determined input tax recovery rates are set annually allowing the banks and financial institutions to calculate recoverable input tax credit without the need to specifically identify or apportion the input tax to the various categories of suppliers.

Apart from these schemes, extensive public education programmes were undertaken by the government including seminars, television and radio programmes, advertisements etc. to create awareness on the rationale and mechanism of GST and to get businesses GST ready. Government also ensured that different views on GST did not get aired publicly. A Committee against GST profiteering was also set up in 1994 to investigate complaints on unjust price hike using GST as an excuse.

In 2003, based on the recommendations of the Economic Review Committee, the GST rate was hiked from 3 to $4 \%$ and to 5\% in 2004. Again with effect from 1 July 2007, the GST rate was surged to 7\%. Each increase was accompanied by an offset package to make the people better off by reducing the regressivity of the tax. Direct taxes were also slashed, continuing its practice of lowering direct tax rates since 1986.

\subsubsection{Impact of GST on Singapore's economy}

Overall, GST had a positive impact on the economy in terms of buoyant revenues and exports. GST generated revenue of SGD 1.6 billion in 1994-95 against an original estimate of SGD 960 million. Between 1995 and 2002 the GST contributed about 8 to $10 \%$ of the total tax revenue which further increased to $13 \%$ and $14 \%$ in 2003 and 2004 respectively. In the year 2015 the share of GST in the total tax revenue of the government was $23 \%$ making it the second largest source of tax revenue of the 
government (IRAS website). Because of MES and BWS systems introduced by the government, total exports grew at a rate of $18.91 \%$ in $1994-95$ as compared to the growth rate of $13.49 \%$ in 1993-94 (Jenkins and Khadka, 1998).

Consumers were not greatly affected by the implementation of GST as inflation rose by less than expected. Inflation rose from 2.3\% in 1993 to $3.1 \%$ in 1994 as against expected of $5.5 \%$. Thereafter it moderated to $1.7 \%$ in 1995 and to $1.4 \%$ in 1996 (Jenkins and Khadka, 1998). The reasons for low increase in general price level were temporary absorption of the GST by the retailers and by government on public healthcare and education. Government's monitoring of the prices, action against unfair profiteering and tight control over the monetary policy also ensured that inflation could not increase.

Since businesses in Singapore did not have any prior experience with the general sales tax system, so it was difficult for them in the beginning to learn about the system and its application. Initially the compliance cost was higher for small traders as compared to bigger ones but it declined as businesses became familiar with the GST system. Administration of GST was also smooth and efficient. New issues were handled quickly which helped to win the confidence of businesses. Mobiles teams were also set up to handle problems immediately as they came across. Extensive audit and investigation was carried out to encourage compliance by businessmen and circulars were sent to all GST registrants pointing out the errors and advising them to avoid them. Substantial amount of GST was recovered over the years as a result of such audits.

Poh and Pope (2000) and Poh (2003) evaluated the impact of offset packages in addressing the regressivity of GST for 1994 and 2003/04 reforms respectively. Offset packages proved to be effective, fiscally efficient and administratively convenient with a high take up rate. When the GST rate was raised from 5\% to $7 \%$ in July 2007, a household in the bottom $20 \%$ had to pay additional GST of $\$ 370$ per year, but received an offset package of $\$ 910$ per year, in addition to permanent benefits of $\$ 1,000$ per year. Singapore had no experience of a general type of consumption tax before the introduction of GST yet its implementation had been very smooth and can be regarded as best practices framework which can provide guidance to other governments such as India towards successful introduction of a broad based value added tax.

\subsection{Value Added Tax in Philippines}

Value added tax was implemented in Philippines in 1988 as an outcome of the 1986 Tax Reform Package. VAT replaced the sales/turnover tax and few other indirect taxes. The indirect taxation system prior to 1988 was complex and was hampering the economic growth of Philippines because of low revenue generating capacity, cascading effect, poor compliance and administration. VAT replaced the advance sales tax, 
subsequent sales tax, compensating tax, Miller's tax, broker's tax, contractor's tax, some taxes on services and excise taxes on few products.

VAT was introduced as a broad based consumption tax levied on value added basis at each stage in the supply chain from manufacturer till the consumer and on the import of goods and services in Philippines on a destination basis at a uniform rate of $10 \%$. To address regressivity, sale of essential commodities like unprocessed agricultural and marine food products have been kept exempt from VAT. Exports are zero rated and an additional $20 \%$ tax is levied on luxury items like gems and jewellery, perfumes, yacht and other vessels for pleasure and sports.

In order to widen the VAT base and improve compliance and administration, Philippines government on $5^{\text {th }}$ May 1994 approved the Republic Act 7716 popularly known as the Expanded VAT Law. E-VAT came into effect from November 1, 2005 at a uniform rate of $10 \%$. The E-VAT rate was increased from $10 \%$ to $12 \%$ in February 2006. Main objectives to introduce E-VAT were to restructure the pre-existing VAT system; broaden the VAT base by lifting exemptions; address the ballooning fiscal deficit by generating additional revenues for the government and to improve government services and programs such as health, social security, education and other infrastructure projects.

In order to effectively implement E-VAT, the Bureau of Internal Revenue (BIR, the administrative authority of VAT in Philippines) developed a new, more organised system of monitoring, evaluation and VAT collection known as the Benchmarking method that facilitates the determination and comparison of the performance level of businesses in the same industry. Benchmarking enables Revenue District Officers to identify taxpayers who are declaring Income Tax and net VAT dues lower than the minimum amount set per industry group.

\subsubsection{Impact of E-VAT on Philippines}

One of the immediate effects of the E-VAT was the increase in prices of goods and services because the VAT rate was increased from $10 \%$ to $12 \%$. In addition, the other goods and services which were previously VAT exempt became subject to VAT. In terms of the change in inflation, there was an increase by $0.84 \%$ during the bottom half-year of 2005 and this further increased to $0.97 \%$ in 2006. Seeing the immediate effect that the implementation of EVAT had, some measures were taken to lessen its effect such as removal of the franchise tax on power distribution utilities which serves to temper the effects of imposing VAT on power and reduction of excise tax on petroleum products such as kerosene, diesel and bunker fuel oil. In addition, authorities announced plans to spend $30 \%$ of the incremental revenue receipts from the VAT reform on 
infrastructure and social services, which could further ameliorate any adverse distributional effects.

Newhouse and Zakharova (2007) who assessed the distributional impact of the E-VAT reform in the Philippines concluded that the reform was progressive and relatively well targeted but a sizable amount of the benefit accrued to high-income households. Households in the bottom quintile enjoy only about 15 percent of the benefit from the package of tax cuts and spending increases, while households in the top quintile enjoy about $30 \%$ of the benefit.

On a positive note, E-VAT enabled the government to obtain additional revenues of PHP 81.4 billion in 2006.In the year 2014 the share of VAT in the total tax revenue of the government was $15 \%$ making it the second largest source of indirect tax revenue for the government (Revenue Statistics of the Asian countries, 2016, OECD). The next round of VAT reforms in Philippines are focused on broadening the VAT base, increasing the VAT rate and simplifying the tax administration as presently, the Philippines government is planning to raise the VAT rate from $12 \%$ to $15 \%$ and lifting VAT exemptions on around 30 products and services along with increase in excise tax on fuel.

\subsection{Value Added Tax in Thailand}

In Thailand, VAT came into existence on 1 January 1992 replacing the preexisting business tax. Business tax acted as a major obstacle in Thailand's economic growth and international competitiveness. Since business tax was an ad valorem tax levied on every transaction, it used to get accumulated along the chain of production. Thus, an initial tax rate of $10 \%$ could turn into an effective rate of over $25 \%$ depending upon the number of intermediate stages in their production. This led to various problems such distortions in production decisions, high cost of production and incentives for vertical integration. Also, business tax system was confusing as there were 21 different BT rates on different goods and services. So, by replacing the business tax with a VAT, Thailand could achieve a more uniform tax rate throughout the economy. Thailand introduced VAT in January 1992 as broad based consumption tax levied at each stage in the supply chain on the supply and import of goods and services in Thailand at a single uniform rate of $7 \%$ with the benefit of input tax credit of previous purchases. The rate went up briefly to $10 \%$ following the economic crisis in 1997 but was quickly reduced in 1999 in the light of dire economic conditions to stimulate the consumption demand. The rate is $7 \%$ since 1999 .

There are several items which are exempt from VAT. In addition, there is a zero rate levied on transactions such as exporters of goods and services, producers of 
investment goods, sale of goods and services to United Nations and its specialised agencies etc. In such transactions traders are not required to pay VAT and will also receive a rebate for the taxes paid on their inputs. Apart from the VAT there is other type of sales tax known as the excise tax that is selectively imposed on a no. of commodities. Excisable items are also liable for VAT. Local governments receive $10 \%$ of total VAT revenues.

\subsubsection{Impact of VAT on Thailand's economy}

Introduction of VAT led to short-term inflation in Thailand. However measures undertaken by the government such as price control on certain items eased the situation. Insufficient understanding of the VAT system also led to dumping of the products by some of the businesses in market who believed that prices would decline post VAT due to lower tax burden. The tax credit process was delayed due to insufficient no. of tax officials and the revenue department was criticized by the traders. VAT refund represents a strong inefficiency in the VAT collection.

Despite its criticism, VAT proved to be buoyant in terms of generating revenues to the Thai government. For the fiscal year 1998-2003 the share of indirect taxes in the total tax revenue was 58\% (Sujjapongse, 2005). VAT is just the second main source of indirect taxes after the excises. Another problem was non-compliance both in the formal and informal sectors. The main actions underway to improve taxpayer compliance are: tightening of the rules regarding VAT refunds, the development of automated systems for the VAT refund and for the audit case selection, the reduction of taxpayer compliance costs, the simplification of VAT's forms and an increase of registered VAT taxpayers.

Presently, Thai government is planning to increase the VAT rate to $10 \%$. But since VAT is imposed on the consumption of goods and services, an increase in the rate potentially will hamper the consumption and will negatively affect the economy. Thai economy is currently showing negative signs such as sluggish consumption and high household debt. However, in the long run, the VAT rate may need to return to $10 \%$ due to the growing fiscal deficits along with rising public debt. Thai government has been carefully reviewing the overall tax structure to achieve sustainable and broad based development and to transform Thailand into a more competitive economy.

\subsection{Value Added Tax in Vietnam}

The Vietnamese VAT system is among the most complex in ASEAN. While eight countries in the region have a VAT, only Vietnam's VAT system has more than one rate with large list of exemptions. Prior to 1999 a Turnover tax, ranging from 0.5 to 
40 per cent, was levied on gross sales revenue. Criticised for its cascading effects, the 'turnover tax' was replaced by a VAT in January 1999. The need to introduce VAT in Vietnam arouse when the second phase of reform was initiated in late 1990s. Vietnam signed ASEAN Trade Freedom Agreement (AFTA) and was preparing for negotiations on World Trade Organization (WTO) access with the introduction of modern taxes such as value-added tax and corporate income tax. In 1995, the National Assembly ratified the decision to introduce VAT in order to eliminate the weaknesses of the existing turnover tax such as cascading effects, hurting the international competitiveness and multiple rates for competing goods and services. Keeping in mind the above objectives, the VAT law was passed in Vietnam in 1997 and finally implemented in January 1999 as a broad based consumption tax levied on sale of goods and services in Vietnam at each stage in the supply chain with the benefit of full input tax credit.

The VAT was initially levied at three rates: $5 \%, 10 \%$ and 20\%. Exported goods and services were taxed at zero percent while 26 categories of goods and services were exempt. Since January 2004, the number of VAT rates has been reduced to two: 5\% and $10 \%$. Similar to the 1999 VAT law, zero rate is applied to goods and services traded across borders, 26 goods and services are exempt from this tax net, while 5\% rate is applied to 15 categories of essential goods and services. The standard rate still remains at $10 \%$. In recent years, the Vietnamese indirect tax system has been simplified. Nevertheless, a wide range of tax rates and exemptions remain. An interesting feature of Vietnamese VAT is that no VAT registration threshold applies, and no exemption from registration is provided.

\subsubsection{Impact of VAT on Vietnam}

Implementation of VAT and its compliance is not an easy task especially for developing countries which lack sufficient resources and information technology required for administration of a broad based value added tax. Same was the problem with Vietnam where the law was implemented on a trial and error approach. Neither the authorities nor the taxpayers were aware of what was happening since VAT came into effect from $1^{\text {st }}$ January 1999 . The problem was both with the complex VAT law and its implementation.

Multiple VAT rate structure created complexity for businesses which could not make clear distinctions. Many firms applied VAT rates on their products despite being outside the purview of VAT because of lack of knowledge about VAT laws. Introduction of VAT led to inflationary situation in Vietnam which reduced the purchasing power of people. Some businesses found VAT as an excuse for raising prices of their products. Increased compliance cost under VAT was met by increasing the selling price of goods 
and services. However, government strictly issued a directive to not to increase prices for the first six months post VAT implementation. Government also formed a committee to strictly enforce the directive. As a result many companies were forced to repay additional money charged from their customers and revert to their former prices.

Considering the majority of small businesses which are household enterprises that do not maintain detailed accounts, government of Vietnam made the compliance under VAT simpler for them. Small scale businesses are required to pay VAT using a direct method as opposed to the invoice credit method. However the major drawback of this scheme is that businesses buying goods and services from those which are under the direct method will not be allowed to claim input tax credit.

Despite the negative impact of VAT on some sectors, VAT had a buoyant impact on government revenues. The share of VAT in the total tax revenue of the government has increased from around 22\% in 2006 to $30 \%$ in 2012. The tax structure in Vietnam has evolved from an initial high reliance on production and trade taxes to a greater reliance on consumption taxes because of stability of VAT as a source of revenue.

\subsection{Comparison of VAT/GST Structure of India with Selected ASEAN Economies}

In this section, a comparison has been made between the Indian GST structure and the VAT/GST structure of the selected ASEAN economies on the basis of certain parameters with the objectives of finding out the similarities and differences of the Indian GST system with that of its ASEAN counterparts. An attempt is made to draw lessons for India which it can adopt in its GST system to make it more efficient and administratively smooth. The main points of comparison have been discussed below.

\subsection{Federal versus Unitary form of government}

The nature of the form of government has an implication on the manner of levy of GST/VAT and its administration. All the countries selected for the study have a unitary form of government except for Malaysia and India which are federal economies where the taxing powers have been divided between the central and state governments by the constitution. Since Singapore, Indonesia, Philippines, Vietnam and Thailand have a unitary form of government, VAT/GST is levied, collected and administered by the central government. In Malaysia, two levels of governments have combined their levies in the form of a single national GST with appropriate revenue sharing arrangements among them. VAT/GST is levied and administered by the central government. State 
governments depend upon transfers from the federal government for revenues to meet their expenditures.

On the hand, India has a unique 'dual GST model' which has not been implemented by any of the federal economies in the world. India has adopted a 'clean dual GST' model' wherein GST has two components, one levied by the Central government known as the Central Goods and Services Tax (CGST) and other levied by the state governments known as the State Goods and Services Tax (SGST) to promote cooperative federalism. Both CGST and SGST are levied simultaneously on the common base and at the same rate on every taxable transaction of supply of goods and services in India. Dual GST model is implemented through multiple statues, one for CGST and another SGST statue for every state. Another component is Integrated Goods and Services Tax (IGST) which is levied on inter-state supply of goods and services; import of goods and services in India and supply of goods and services to or by Special Economic Zones developer or unit. Administration of GST is also dual in India. State authorities will audit and scrutinize $90 \%$ assesses who have an annual turnover of Rs. 1.5 crore or less, while the centre will assess remaining $10 \%$. Those with turnover of over Rs. 1.5 crore will be equally divided between centre and state- $50 \%$ each. Each assesse will be assessed by only one tax authority.

\subsection{Single versus multiple rate structure}

All the selected countries under this study levy VAT/GST at a single uniform rate on all taxable goods and services with zero rating of exports except for Vietnam and India. Vietnam is an exception in ASEAN which has adopted a two rated VAT system apart from zero rating of exports. Singapore being a developed economy has adopted a broad based GST structure with a low uniform rate levied on the consumption of all the taxable goods and services with only few exemptions. In Singapore, the problem of regressivity caused by the broad based GST is dealt outside the GST system by offering large scale compensating packages to lower income households. These offset packages have proved to be successful in addressing regressivity in Singapore because of efficient administration and good fiscal condition of the government.

Developing countries in ASEAN like Philippines, Indonesia, Malaysia and Thailand also levy VAT/GST at a single uniform rate but follow a narrow based VAT/GST with large scale exemptions to protect consumption demand of poor households since large scale of population falls below the poverty line. But proliferation of exemptions results in cascading effects, administration and compliance problems and lower revenue generating capacity for the government as evidenced from these countries. 
On the other hand developing countries like India and Vietnam have adopted a multiple rate structure with comparatively few exemptions to address regressivity of VAT/GST. The four slab rate structure of GST followed by India is:

(i) Lower rate of $5 \%$ on essential items;

(ii) Two standard rates of $12 \%$ and $18 \%$ on majority of goods and service;

(iii) Higher or sin rate of $28 \%$ on other consumer goods such as small cars;

(iv) $28 \%+$ cess on tobacco, luxury cars, pan masala etc.

Cess has been recommended to fund compensation for revenue loss to states. India adopted a multiple rate structure because it better addresses the problem of regressivity in a developing country like India where a large number of people lie below the poverty line. It also protects against revenue loss resulting from large scale exemptions. Further administrative issues, fiscal deficits and problem of last mile connectivity prevents Indian government from addressing regressivity by offering compensating offsets as done by Singapore. However, multiple rates increases both administrative complexity and compliance costs as well as results in classification disputes as evidenced from Vietnam and even from the present situation in India post GST implementation in July 2017. Various sectors whose goods and services have been fitted at the higher rate slab have started lobbying with the government for placing them at a lower rate.

\subsection{Taxes replaced by VAT}

In India, GST has replaced majority of indirect taxes and cesses levied by the central and state governments including excise duty, services tax, VAT etc. but in other ASEAN countries like Thailand excise tax is still prevalent apart from VAT/GST. In Indonesia a high luxury tax on goods and services is levied apart from VAT. Simultaneous existence of other indirect taxes along with VAT/GST is also one of the reasons why ASEAN countries have adopted a uniform rate of VAT while India has adopted a multiple GST rate structure to maintain revenue neutrality of the indirect tax system apart from addressing the regressivity of the broad based value added tax.

\subsection{Type of VAT/GST}

India and other selected ASEAN countries have adopted a consumption type of VAT wherein taxpayers are permitted to deduct the full value of VAT/GST paid on capital goods immediately in the year of purchase. Philippines is an exception which have adopted an income type of VAT. In Philippines a taxpayer can claim the credit of VAT paid on capital goods over 60 months beginning from the month of acquisition. Contrary to the income VAT, consumption VAT encourages investment in capital goods 
rather than penalising them. Consumption VAT has overcome the limitation of the preexisting CENVAT or central excise duty in India wherein input tax credit of excise paid on capital goods was available in two instalments over two years leading to cascading effect. Consumption type of GST will encourage investments in capital goods by manufacturing firms and provide a boost to the Make In India initiative.

\subsection{System of getting input tax credit}

Except Vietnam, all the selected countries including India have adopted an invoice based input credit system where VAT on inputs is allowed as a deduction from the VAT payable on sales on the basis of the VAT indicated on invoices. A tax invoice must be issued when a VAT/GST registered person makes a taxable supply. A valid purchase invoice must be held as an evidence to claim input tax credit. Vietnam has adopted a dual method of calculating VAT liability. One is invoice credit method applicable on majority of businesses maintaining full proper books of accounts, invoices and documents in accordance with the relevant regulations. Another is the direct or subtraction method applicable on small scale businesses which do not maintain proper books of accounts and invoices. This method reduces compliance burden on small scale businesses but it is difficult to combat tax evasion because of lack of invoices as an evidence of sales and purchases. India too could have opted for this method since majority of businesses in India are small and medium scale. However, opting for deduction method would have resulted in sacrificing ease of enforcement and administration for ease of compliance.

\subsection{Electronic filling of returns}

Electronic filling of returns is not mandatory in the countries selected for the study except for Singapore (where it was made mandatory with effect from 1 January 2007) and India. India has developed a large scale sophisticated information technology system known as Goods and Services Tax Network (GSTN) which is tasked with providing information technology infrastructure for GST. GSTN portal provides a one stop destination for filling and processing of all taxes. Registration, filling of returns, tax payments, submission of invoices, claiming GST refunds and input tax credit all have been made compulsorily online. This will make the administration easier and help curb tax evasion.

\subsection{Lessons for India}

Based on the analysis of the structure of VAT/GST of the selected countries under the study and the impact of the tax on their economy, certain lessons can be drawn 
for India so that it is wary of the problems faced by them and initiate special programmes as undertaken by these countries to resolve economic/sector specific issues, and to improve tax compliance and administration which is key to success for a broad based value added tax. Some of the lessons which can be drawn from the experience of selected countries are as follows:

(i) One of the aspects of GST which is accepted worldwide is that it is inflationary in the short run, if not in the long run. Countries under this study saw a hike in inflation although for a short period of time when GST was implemented. However, effective administration and anti-profiteering measures taken up by these countries enabled to mitigate the price hike in the long term. This provides lesson for Indian administrators to keep control on prices after imposition of GST. Although Indian GST Law has an antiprofiteering clause to combat unjust price rise by businesses and a special Antiprofiteering Committee has also been established to oversee complaints regarding unjust price hike post GST but its success will entirely depend upon efficient administration.

(ii) Malaysia's experience provides a lesson that businesses need to start early with the implementation process to be GST ready. The Malaysian government received strong resentment from the business community even after providing 1.5 years for GST preparedness. Given the complex multiple GST rate structure in India and the need for businesses to undergo a transformation with huge added compliance burden, it would be quite challenging for the Indian government to tackle the task of requiring businesses to implement GST in less than a month after final classification of goods and services under different slabs was done in June 2017 with 1 July 2017 as the date of implementation of GST.

(iii) In addition, the Indian GST regime places the SMEs on the same footing as large industries by keeping the exemption threshold very competitive i.e. Rs.20 lakhs which will pose problems for SMEs who lacks sufficient resources with them to comply with GST provisions as compared with their large counterparts. Some post- GST truths from GST in Malaysia includes widespread unrest and anti-GST street protests by SMEs businesses in Kuala Lumpur for few months after implementation, despite simpler requirements and much higher thresholds. The same scenario was been observed in India as many SMEs belonging to different sectors like textiles, food grains etc. did anti-GST protests all over India demanding either exemptions or lower compliance burden under GST.

(iv) For small and medium scale businesses who do not have sufficient resources and technological know-how and have low profit margins, some kind of grants or fund should be set aside by the Indian government which could be devoted for providing subsidies to the SMEs for cost incurred in installing accounting softwares for GST as 
done by the Malaysian government. Alternatively, government can allow them to retain a percentage of tax collected to compensate them for their substantially higher compliance cost or can subsidise their overall compliance cost in certain proportion of their compliance cost.

(v) Another lesson for India from Malaysian experience is to maintain adequate no. of experienced tax agents to handle taxpayers' grievances post GST implementation. Singapore is the best example in handling grievances post GST in a quick and efficient manner by setting up a fly squad team which reached the place of grievance quickly and resolved the issue.

(vi) The Malaysian government was not prepared for the large amounts of refunds that needed to be made to the GST registrants. So India should learn from Malaysia's mistake and should be well prepared for timely refunds to exporters and other taxpayers so that they do not face any cash flow problems. India can also adopt Malaysia's GST Audit Blue Ocean Strategy to conduct audits post GST implementation to improve compliance. (vii) Singapore's preparation and introduction of full-fledged successful GST in barely 15 months from February 1993 to April 1994 sets an example for India that careful planning, detailed preparation, strong political commitment, mass participation, extensive taxpayer education program and good timing are essential ingredients for successful implementation of a value added tax system.

(viii) Other lessons which India can take from Singapore are: efficient administration and quick redressal of taxpayers' grievances; adopting major export scheme to relieve exporters from claiming GST paid on imports at a later time period which would reduce their working capital requirements as well as reduce their compliance burden and carrying out extensive audits post GST implementation to improve compliance among businesses.

(ix) India should also learn from the administrative problems faced by developing countries such as Philippines, Vietnam, Thailand and Indonesia. Their experience illustrates that VAT should be designed to be simple, neutral and as clear as possible avoiding excessive exemptions and derogations. Otherwise the administrative and compliance cost will be high and tax evasion will be more difficult to control.

(x) Another lesson which can be drawn from these countries is that, to prevent possible VAT evasion, a sound accounting and an advanced information management system is a must along with the effective governmental regulation which lacked in these countries. Although India has developed a large IT system known as Goods and Services Tax Network (GSTN) with an inbuilt invoice matching system but its soundness would be known after it comes into practice post GST implementation. 


\subsection{Conclusion}

Tax administration has a crucial role in ensuring the effectiveness of a tax policy. However, implementation of VAT and its compliance is not an easy task especially for developing countries which lack sufficient resources and information technology required for administration and improved compliance of a broad based value added tax. This is evidenced from the analysis of this study. In case of developed ASEAN countries like Singapore better administration led to an increase in indirect tax revenues and smooth implementation of GST/VAT. On the other hand, developing countries like Philippines, Vietnam, Malaysia, Thailand and Indonesia although saw an increase in their indirect tax revenues but encountered administrative and compliance problems (especially for small and medium scale businesses for whom compliance costs increased in higher proportion than their larger counterparts) post GST/VAT implementation.

Administration of the dual GST model is the biggest challenge facing India. India should learn from both the pitfalls in administration and application of law in developing countries and successful administrative strategies of the developed countries like Singapore. There is a need for proper audit plan(to minimise the gap between the reported and actual statutory tax liability of the taxpayer) to cover different economic activities and large variety of taxpayers as done by Singapore and Malaysia. Although India will follow the electronic e-filling and invoice matching system which will make it difficult to evade taxes. However collusion among the trading partners in the distribution chain can lead to tax evasion. So regular audits are necessary in India post GST's implementation. Apart from this adequate training is necessary for both taxpayers and enforcers. Government should ensure that they have adequate number of experienced tax agents to handle taxpayers' grievances and should be well prepared for timely refunds to exporters and other taxpayers so that they do not face any cash flow problems.

Other issues that still need to be resolved include cascading effect caused by keeping petroleum products outside the purview of GST because petroleum products are widely used as inputs in most sectors. It will hamper export competitiveness of the domestic industries. Also levies and actions by the state authorities could spoil the advantages of lower prices under GST, especially on the same goods and services that attract GST. For example, auto companies cut prices after the rollout of GST on 1 July 2017, but Maharashtra government raised the one time registration levy for new private vehicles by $2 \%$. GST has subsumed as many as 17 central and state taxes and 23 cesses but there are enough items like stamp duty, registration fees, electricity duty, entry and entertainment tax levied by local bodies which are outside its purview that can serve to 
offset the gains of this momentous reform. Thus while the GST aims at unifying multiple taxes, it still leaves out some.

Companies have reported improved logistics efficiency after states have abolished check posts. Shipments are now reaching faster and for some companies, transit time has reduced by $30 \%$. However, employees of Regional Transport Office have emerged as new bumps to faster movements. They have emerged as enforcers of new 'inspector raj' on roads posing new barriers by seeking monthly payments for various charges thereby undermining the beneficial, common market effects of GST. State and local governments should not be tempted to raise stamp duties, levy higher VAT rates on alcohol or fuel or other taxes outside GST and let the benefits of GST reach consumers to set the best example of cooperative federalism.

We hope that all the issues and challenges emerging post GST implementation are resolved expeditiously and India learns from the from the experience of other countries so that India is wary of problems faced by them and initiate special programmes as undertaken by these countries to resolve economic/sector specific issues and to improve tax compliance and administration which is key to success for a broad based value added tax.

\section{References}

Dao, L., \& Binh, T. (2013). Imapct of tax structure system on GDP and progressivity: The case of Vietnam. International Journal of Innovation and Applied Studies, 4(2), 359-365.

Gupta, S. (2016). Goods and services tax: A comprehensive and uniform indirect tax reform in India. Vision: The Journal of Indian Taxation, 3(2), 31-53.

Jenkins, G., \& Khadka, R. (1998). Value added tax policy and implementation in Singapore. VAT Monitor, 9(2), 35-47.

Jin, D., \& Jin, W. (2013). On the development strategy of China's value-added tax (VAT) reform. Journal of Chinese Tax and Policy, 3(special issue), 226-237.

Kasipillai, J., \& Krever, Rick. (2016). Malaysia's GST journey: Past, present and future. VAT Symposium on VAT in Developing Countries: Policy, Law and Practice. 19-20 October, Pretoria, South Africa. Retrieved from www.up.ac.za/media/shared/58 /ZP_Files/2016/.../y-kasipillai_r-krever.zp103870.pdf 
102 | VISION: Journal of Indian Taxation, Volume 4, Issue 1, January-June 2017

Newhouse, D. \& Zakharova, D. (2007). Distributional implications of the VAT reform in the Philippines. IMF working paper no. 07/153. Retrieved from SSRN: https://ssrn.com/abstract=1007902

Palil, M. R., Ramli, R., Mustapha, A. F., \& Hassan, N. S. A. (2013). Elements of compliance costs: Lesson from Malaysian companies towards goods and services tax (GST). Asian Social Science, 9(11), 135-147.

Poh, E., \& Pope, J. (2000). Addressing the regressivity of a Goods and services tax: Lessons from Singapore's tax reform. Australian Tax Forum, 15(4), 459-503.

Poh, E.H. (2003). Moderating the distributive impact of the increase in the GST rate in Singapore. Asia-Pacific Journal of Taxation, 7(3), 53-79.

Public Sector Finance, Economic Report (2016-17). Ministry of Finance, Malaysia. Retrieved from http://www.treasury.gov.my/index.php/en/economy/economic-report. html

Ruangmalai, R. (1993). Value Added Tax in Thailand. Revenue Law Journal, 3(2), 135142.

Sujjapongse, S. (2005). Tax policy and reform in Asian countries: Thailand's perspective. Journal of Asian Economics, 16(6), 1012-1028.

Venkadasalam, S. (2014). Implementation of Goods and service tax (GST): An analysis on ASEAN states using Least Squares Dummy Variable Model (LSDVM). Paper presented at International Conference on Economics, Education and Humanities (ICEEH'14), December 10-11, Bali, Indonesia. 